\title{
What do Students Really Understand? Secondary Education Students' Conceptions of Genetics
}

\author{
Didem Kılıç Mocan \\ Aksaray University, Faculty of Education, Aksaray, Turkey
}

\begin{abstract}
Individuals with a secondary education should have a knowledge level sufficient to make sense of what they read or hear about genetics, and they should be able to think scientifically in evaluation and decision-making processes. The purpose of this study is to identify the basic understanding of secondary education students about genetic concepts and the reasons for the difficulty of learning and teaching genetics. Semi-structured interviews that include student drawings have been conducted with 24 students to gain a comprehensive perspective on secondary education students' understanding of the basic concepts of genetics. The answers given by the students to the interview questions and their drawings have been analyzed with content analysis. Qualitative data analyzed with a holistic point of view were collected and evaluated under the categories of 'DNA, gene and chromosome' and 'Cell divisions and heredity relationship.' As a general result, it has been found that students have inaccurate and inconsistent information about the basic concepts of genetics, have difficulties in establishing relationships between these concepts, and cannot fully understand and explain the processes underlying genetic events. It has been observed that various factors have an effect on this result. It will be possible to support students to develop a more accurate understanding of genetic concepts and issues by working on the weaknesses in genetics teaching, providing an enriched teaching environment with current teaching methods and materials, and moving away from rote learning.
\end{abstract}

Science Insights Education Frontiers 2021; 10(2):1405-1422.

Doi: 10.15354/sief.21.or061

How to Cite: Kllıç Mocan, D. (2021). What do students really understand?

Secondary education students' conceptions of genetics. Science Insights Edu- 
Kılıç Mocan (Turkey). Secondary Education Students' Conceptions of Genetics. cation Frontiers, 10(2):1405-1422.

Keywords: Genetics Teaching, High School Students, Genetic Concepts, Secondary Education

Correspondence to: Didem Kllıç Mocan, Associate Professor, Aksaray University, Faculty of Education, Aksaray, Turkey.E-mail:didem_kilic@yahoo.com

Conflict of Interests: None.

(C) 2021 Insights Publisher. All rights reserved.

cc) (i) (2) Creative Commons Non Commercial CC BY-NC: This article is distributed under the terms of the Creative Commons Attribution-NonCommercial 4.0 License (http://www.creativecommons.org/licenses/by$\mathrm{nc} / 4.0 /$ ) which permits non-commercial use, reproduction and distribution of the work without further permission provided the original work is attributed by the Insights Publisher. 


\section{Introduction}

W

ITH the discovery of the molecular structure of DNA, genetics has become one of the most important subjects in biotechnological research that accelerated revolutionary developments in many applied fields such as medicine, agriculture and animal husbandry, and especially industry. Today, hereditary diseases can be diagnosed prenatally, new drugs and vaccines can be developed, cancer can be diagnosed and effectively treated at much earlier stages, compatible organ transplants can be made, and efficient, durable, and nutritious food products can be produced with gene technologies. While discoveries in the field of genetics provided new insights into some fundamental problems of evolution, the origin of life, and the structure of living things (Okebukola, 1990), they also made significant contributions to people's understanding of the living environment, including themselves.

Rapid developments in gene technologies bring along some social, economic, and ethical questions. According to Marbach-Ad (2001), members of a society need to receive an effective education to understand and answer these questions. Genetics education plays a major role in raising knowledgeable and responsible individuals, both to prevent scientific developments from being interrupted by unnecessary concerns, and to protect human rights and ensure environmental awareness. Learning about genetics is considered a very important part of scientific literacy, which has a decisive role in the scientific thinking and decision-making processes of citizens (Boerwinkel et al., 2017; Haskel-Ittah et al., 2020). With the increasing importance of genetics in daily life, it is emphasized that more attention should be given to issues related to genetics in education systems (Hott et al., 2002) and genetic literacy should become more widespread (Kawasaki et al., 2021). In the studies conducted by Lewis et al. (2000a; 2000b; 2000c), it is stated that new developments and research in the field of genetics are the subjects of news every day, and societies should be scientifically literate in genetics to understand developments in the field of medicine. It is argued that individuals with a secondary education have a knowledge level sufficient to make sense of what they read or hear about genetics and should be able to participate in the decision-making processes.

The biology subjects that students have difficulty in understanding were first researched by Johnstone and Mahmoud in 1980 and genetics was identified as one of the subjects that students have the most difficulty in understanding. Studies conducted in the following years have revealed that genetics is among the subjects that students have difficulty in understanding (Bahar et al., 1999; Banet \& Ayuso, 2000; Duncan \& Reiser, 2007; Finley et al., 1982; Kablan, 2004; Kılıç \& Sağlam, 2014; Kindfield, 1991; Marbach-Ad \& Stavy, 2000; Rotbain et al., 2005; Stewart, 1982; Tekkaya et al., 2001). Dorji et al. (2017) report that the number of studies showing that high school students graduate with extremely weak and inadequate knowledge in the field of genetics is increasing.

Evaluating the studies in genetics education, Knippels et al. (2005) list the reasons for these difficulties as the field-specific terminology, the mathematical content in Mendelian genetics, cellular processes in genetics, abstract genetic concepts, and the 
complex nature of genetics. According to Duncan and Reiser (2007), another reason that students have difficulty in understanding genetics is that genetic events are invisible and inaccessible. Most of the genetic concepts are classified as theoretical concepts because they are hypothetical and imaginary concepts. Therefore, students need to be able to think hypothetically to understand theoretical genetic concepts (Baker \& Lawson, 2001). In addition, the necessity of logical thinking that is at the core of high-level thinking skills in order to understand genetic concepts is another reason that explains the difficulty in understanding genetics (Banet \& Ayuso, 2000). Another reason that genetics topics are difficult to learn and teach is that these topics involve concepts (such as genes, proteins, cells, tissues, organs) that belong to different levels (macro, micro, and molecular levels) of a biological organism. To understand the processes underlying genetic phenomena, students need to be able to integrate these different levels into the bigger picture so that they can understand genetics as a whole (Bahar et al., 1999; Duncan \& Reiser, 2007; Marbach-Ad \& Stavy, 2000). According to Rotbain et al. (2005), difficulties in understanding genetics increase especially with molecular level concepts, because teachers and books use chemical formulas and abstract and complex figures to demonstrate the structure of molecules. In addition, the similarity of genetic terms in both spelling and pronunciation (Bahar et al., 1999) and the synonymous words in genetic terminology (Pearson \& Hughes, 1988a) make it difficult for students to understand genetics by making them confuse these concepts with each other.

After the teaching of genetics, students have information about related concepts, but they often misunderstand these concepts and related issues. This is because knowledge is necessary but not sufficient to understand the subject. To understand the subject, connections must be made between information and relationships must be comprehended. As explained by Ausubel (1968), meaningful learning occurs when students consciously associate new knowledge with related concepts and processes (Okebukola, 1990; Wandersee, 1985). If the new information conflicts with the existing knowledge or if the students lack the necessary knowledge to understand new information, they have difficulty in comprehending the subject. Learning the concepts incorrectly or incompletely also negatively affects learning other related concepts. In particular, the correct understanding of some concepts is effective in correctly learning many related subjects on which these concepts are based (Kılıç et al., 2009). The information should be used to solve new problems and to explain new situations. In some cases, students can solve problems without knowing the meaning of the concepts or knowing why, by using various personal processing methods (Banet \& Ayuso, 2000; Hackling \& Treagust, 1984). However, the fact that students can answer the questions correctly does not mean that they have sufficient conceptual understanding to solve these problems (Orcajo \& Aznar, 2005). The student who understands should not only have a valid scientific explanation but also be able to explain the reasons for it. To evaluate students' understanding of concepts, it is important to determine not only the level of knowledge they have but also the reasons on which they base this knowledge. Stewart and Dale (1989) state that students who understand genetics should be able to explain the mechanisms underlying genetics. As stated above, a correct understanding of the basic con- 
cepts in genetics will enable not only understanding the interaction between these concepts but also explaining the mechanisms underlying genetic events. Thus, it will be possible for students to think scientifically about genetics in their evaluation and decision-making processes.

By identifying the knowledge level of students about the basic concepts of genetics and how they explain this knowledge, the reasons for the difficulty in learning genetics will become more understandable. In this way, effective road maps can be made for teaching genetics. This research, which aims to reveal information about possible weaknesses and deficiencies in the teaching of genetics, was carried out with secondary education students. In our country, secondary education comprises the high school period with duration of 4 years. Starting from the 9th grade and successfully completing the 12th grade, students become high school graduates. According to the Turkish education system, high schools are secondary education institutions that prepare students who have completed primary education for higher education. Secondary education students are at a cognitively sufficient level to understand the abstract content of genetics, make logical inferences, and establish cause-effect relationships for the solution of problems. The fact that detailed teaching of genetic concepts and events is included in secondary education programs has also been effective in determining the target group of this study. Also, previous research suggests that high school students do not have enough domain-specific knowledge to adequately explain complex genetic phenomena. In this study, the framework of which was drawn for these reasons, the goal is to identify the basic understanding level of secondary education students about genetic concepts. It is aimed to develop an understanding of the reasons for students' knowledge, deficiencies, and misunderstandings by identifying them, and it is expected to contribute to filling the gaps remaining in genetics education.

\section{Method}

Consistent with the theoretical framework and the aim of the research that focus on student's in-depth understandings of the genetics concepts, this research was conducted in the interpretive paradigm (Cohen, Manion, \& Morrison 2000). The data were generated through detailed, non-directive interviews including student drawings.

Semi-structured interviews were conducted with 24 students to gain a comprehensive perspective on secondary education students' understanding of the basic concepts of genetics. The participating students study at the 9th, 10th, 11th, and 12th grade levels of different secondary education institutions. The reason for selecting students from each grade level for the interviews is to demonstrate the understanding of the students regarding the related concepts and topics and to determine the stages at which conceptual difficulties occur. While determining the number of students to be interviewed, the repeat answers to the interview questions were taken into account, and it was decided that a sufficient number of data were reached at a certain point.

Information on the demographic characteristics of the students participating in the study is given in Table 1. 
Table 1. Demographic Characteristics of the Study Group.

\begin{tabular}{llll}
\hline Demographic Characteristics & & $\mathbf{f}$ & \% \\
\hline \multirow{2}{*}{ Gender } & Female & 15 & 62.5 \\
\cline { 2 - 4 } & Male & 9 & 37.5 \\
\hline \multirow{3}{*}{ Age (yr) } & 16 & 5 & 20,8 \\
\cline { 2 - 4 } & 17 & 9 & 37.5 \\
\hline & 18 & 6 & 25.0 \\
\hline \multirow{3}{*}{ Grade Level } & 19 & 4 & 16.7 \\
\hline Total & 9 th & 5 & 20,8 \\
\cline { 2 - 4 } & 10 th & 6 & 25.0 \\
\cline { 2 - 4 } & 11 th & 7 & 29.2 \\
\hline & 12 th & 6 & 25.0 \\
\hline
\end{tabular}

The pre-knowledge of the students participating in the study on genetics is limited to the scope of the primary school curriculum, and they have not had an extracurricular learning process on genetics. Considering the secondary education curriculum, subjects related to genetics are primarily taught in the 9th grade within the scope of the "Life Science Biology" unit, according to the Biology Curriculum of the Ministry of National Education. Genetic subjects taught in 10th grades are under the unit titles of "Cell Divisions" and "General Principles of Heredity". There is no unit on genetics in 11th grade. In the 12th grade, genetics is taught in the unit "From Gene to Protein", which includes the topics "Discovery and Importance of Nucleic Acids" and "Genetic Code and Protein Synthesis".

A literature review of previous research on the subject was used in the preparation of the interview form (Banet \& Ayuso, 2000; Baker \& Lawson, 2001; Johnson \& Stewart, 2002; Lewis et al., 2000a; 2000b; Lewis \& Wood-Robinson, 2000; MarbachAd \& Stavy, 2000; Venville \& Treagust, 1998; Venville at al., 2005; Wood-Robinson et al., 2000). The translation and adaptation of the questions deemed appropriate for the research were made by biology education experts and items related to the basic concepts of genetics were added to the interview form. As a result, a preliminary interview form consisting of 10 items was created. Expert opinion was taken to ensure the validity of the interview form. The preliminary interview was applied to 2 secondary education students as a pilot study and 1 more question was added to the interview form in line with the data obtained. The questions prepared for the interview were supported with alternative questions and probes, and it was decided in which possible order the questions would be asked.

The interview form has two parts: The first part consists of questions about the basic concepts of genetics, their functions, and relationships. And the second part consists of questions in which students are asked to make various drawings related to these 
concepts. The questions in the interview form are aimed at getting the opinions of the students about the relations between the concepts of gene, DNA, chromosome, genetic information and heredity, and gene-DNA, gene-chromosome, cell divisions-heredity. Finally, in the interviews, the students were asked about the situations in which they had difficulty in learning these subjects, and they were asked to explain the reasons. All of the interviews with the students were carried out by the researcher in a semistructured way. The interviews lasted approximately 30 minutes.

Interview protocols were prepared by transcribing the data, and then the statements in the protocols were arranged. Since non-verbal information is also effective in interpreting the data, non-verbal expressions were also written down. Mayring (2002) and McLellan et al. (2003) recommend transcription rules while preparing protocols, which were taken into account in this study. The rules suggested by Gropengiesser (2001) were also taken into account while making some adjustments so that there would be no change in the content of statements of the students. After the student expressions that emerged in the interviews were organized, the data were analyzed with content analysis. Qualitative data analyzed with a holistic perspective were gathered under categories and evaluated.

\section{Results}

As a result of the students' answers to the interview questions and the analysis of their drawings, the findings were evaluated under two main categories. The first of these relations is DNA, gene, and chromosome, and the second is cell divisions and heredity.

It was seen that students used these concepts interchangeably in their drawings and answers to the questions about the concepts of 'DNA, gene and chromosome' and their locations, functions, and relationships, they could not distinguish them from each other well, and they also had some incomplete and incorrect information. Some direct quotations from student opinions are given below.

Interviewer: What is the reason for people's resemblance to their parents?

Student 8: Because the chromosomes are carried by the gametes, that is, one comes from the mother and one comes from the father, it depends on the characteristics of the mother and father, whether [these features] are dominant or not. (Male, age: $19 \mathrm{yr}, 12 \mathrm{th}$ grade)

Student number 8 states that genetic characteristics are transferred from the parents to the offspring with chromosomes and that the chromosomes are carried by the gametes. However, in the follow-up questions, it was found that the student had the view that chromosomes are only found in gametes. In another statement, student number 11 seems to have a similar view that genes are only found in gametes.

Interviewer: What can you say about genes? For example, where are genes located? 
Student 11: [Genes] [are] found in the gametes. (Female, age: 17 yr, 10th grade)

It is seen that students have difficulty in explaining where genes are located in the body. It is understood that about $33 \%$ of students believe that only gametes contain genes or genetic material.

Interviewer: Where are genes located in our body?

Student 21: Genes are found in DNA cells, in every cell in our body. The genes in reproductive cells already carry our hereditary characteristics. For transmission, they [reproductive cells] are used. (Female, age: $17 \mathrm{yr}$, 11th grade)

Although student number 21 states that genes are found in all cells, she thinks that the genes that carry our hereditary characteristics are found only in the gametes and that gene transfer can take place in this way. It is also seen that the same student has a wrong concept about "DNA cells."

Interviewer: Where is the genetic information that determines eye color found?

Student 5: Our eye color [...] is found in our own gamete so that it can be passed on to our child. After all, you cannot take something from the eye and send it to the sperm cell. (Male, age: $17 \mathrm{yr}$, 10th grade)

Interviewer: There are genes that determine eye color; I gave eye color as an example, where do you think those genes are found? Student 15: [The genes that determine eye color] are either recessive or dominant in $X$ and $Y$. (Female, age: $16 \mathrm{yr}$, 9th grade)

Students of number 5 and number 15 are of the opinion that genes are only found in the gametes or the sex chromosomes. This situation shows that students have difficulty in distinguishing heredity and reproduction processes from each other. Another remarkable answer to this question was given by student number 20 :

Interviewer: There are genes that determine eye color. In which cell are these genes found?

Student 20: It could be the brain. After all, everything is under brain's control. (Female, age: 17 yr, 11th grade)

It is understood that there are students who think that genes are found only in the gametes, as well as those who think that they are found in the sex chromosomes, in the cells of the related organ, or the brain.

Almost all of the interviewed students $(91.6 \%)$ gave similar answers to the question, "Where are the sex chromosomes found?"

Student 3: It's in our gametes. (Male, age: 16 yr, 9th grade) 
Student 5: The male sex cell is found in the sperm or [female germ cell] egg. (Male, age: $17 \mathrm{yr}$, 10th grade)

Student 14: It can be in the cells of the reproductive organs. I don't know exactly, but all of them have it, some of them may not be used or they may be only in the genitals. I'm not sure. (Female, age: $18 \mathrm{yr}, 12$ th grade)

Student 17: In the ovaries and testicles. (Female, age: $17 \mathrm{yr}$, 11th grade)

Some direct quotations from the answers given to the interview questions in which students' understandings of the relationships between the concepts of gene, DNA, and chromosomes are given below:

Interviewer: Is there a relationship between gene and DNA?

Student 17: There is. Genes are ultimately part of DNA, or DNA is part of a gene. (Female, age: $17 \mathrm{yr}$, 11th grade)

Interviewer: Where are the chromosomes located?

Student 9: There are chromosomes in DNA, and there are genes in chromosomes. (Female, age: $17 \mathrm{yr}$, 10th grade)

Interviewer: Where are genes found?

Student 7: Were genes inside our chromosomes?

Interviewer: Can you explain the relationship between gene and chromosome?

Student 7: Was the chromosome also in the gene? (Female, age: 18 yr, 11th grade)

Interviewer: Where are the chromosomes located?

Student 12: Chromosomes are found in DNA. (Male, age: $17 \mathrm{yr}$, 10th grade)

Interviewer: What is the relationship between gene and DNA?

Student 15: DNA, chromosome, gene, where and how [they are found] is a bit complicated (Female, age: $16 \mathrm{yr}$, 9th grade)

It is striking that the students have complex ideas about the concepts of genes, DNA, and chromosomes, especially about their location, and they are not sure of their knowledge. Among the reasons for this is the students' evaluation of these concepts as independent constructs. It is understood that due to the different characteristics of genes, DNA and chromosomes, students have difficulty in understanding that these three different concepts basically perform the same tasks.

The data evaluated within the scope of 'cell divisions and heredity relationship', which emerged as another category after the analysis of the answers given by the students to the interview questions and their drawings, revealed that students have confusion about the concepts and that they cannot establish the relationship between cell divi- 
sions and heredity correctly. Some direct quotations from student opinions are given below.

Interviewer: You have a wide variety of cells; for example, your eye cell, your cheek cell, your liver cell, etc. What do you think is the genetic information in these cells?

Student 15: It is different. It is naturally different since they have different functions. (Female, age: 16 yr, 9th grade)

Interviewer: Do you think the genetic information in your eye cell and liver cell is the same or different?

Student 20: It is different. After all, the eye is for seeing, and the liver has different functions. They are different because they have different functions. (Female, age: $17 \mathrm{yr}$, 11th grade)

In another question asked with the aim of understanding what the students know about the characteristics of genetic information, it was found that the students have wrong ideas. According to this, students think that cells with different functions, structures, or shapes carry different genes. These results are due to teaching mitosis without associating it with heredity. It is understood that the students failed to comprehend that new cells are formed by mitosis during the growth and development of the individual and thus have the same genes as the zygote. Another result that emerged from the students' answers is that the idea that there is a relationship between meiosis and heredity, but that mitosis does not have any relationship with heredity, is dominant.

Interviewer: According to what you said, meiosis has a role in heredity, so what is its function? What does it do, what is its function? Student 14: It enables the creation of new gametes. Variety is provided [with] crossing over (...).

Interviewer: So, does mitosis have an effect or importance in heredity?

Student 14: I don't think so. (Female, age: $18 \mathrm{yr}$, 12th grade)

Interviewer: Does mitosis have any effect on or a role in heredity?

Student 6: I think mitosis has no effect. Mitosis has nothing to do with heredity because it is responsible for the regeneration and proliferation of tissues. (Female, age: 16yr, 9th grade)

Another answer that draws attention among the answers given to the question asked with the aim of revealing what the students know about the relationship between heredity and cell divisions belongs to student number 5. In this quotation, it is seen that the student's knowledge about the characteristics of cell divisions is wrong.

Student 5: Meiosis causes the gametes to be halved. In mitosis, on the other hand, it prevents doubling. (Male, age: $17 \mathrm{yr}$, 10th grade) 
In some quotations, it is seen that students do not know the characteristics of mitosis and meiosis, and they cannot establish their relationship with heredity.

After the questions were completed in the interviews, the students were asked their opinions about why they had difficulty in learning these concepts and related subjects or why they were confused. The students' opinions on this subject give clues about the reasons for the incomplete and incorrect information they have about the concepts and issues related to genetics.

Student 1: We cannot visualize [concepts], I can say that. The fact that these concepts are not displayed visually on the figures causes confusion. In other words, I think it would be much more helpful if the chromatid was explained to us, what a chromosome is, how meiosis happens, step by step, by drawing figures. So I think they should be visualized. We memorize the information, we write it down during exams, and then we forget it. (Male, age: $18 \mathrm{yr}$, 11th grade)

Student 2: [These concepts] are not clearly explained visually. What is a chromosome, what is a chromatid, these are expressed in one sentence, but the concepts are also very close to each other. Knowing the answer to the questions is important in the exam. Chromosome, chromatid, chromatin, they don't matter. And even if you want to study by yourself, the textbooks are not sufficient. Because it is possible to learn it wrong from those sources because the sources are not always very reliable either. When you learn wrong, then it cannot be corrected. It is such a subject that genetics should be explained by someone who knows it very well and has a good command of the subject, you cannot do it by yourself. Other subjects are not so complicated. Genetics is a bit more complicated in terms of concepts compared to other subjects. Other subjects can be understood if you go and study from the source yourself, but genetics cannot be understood. (Female, age: $18 \mathrm{yr}$, 11 th grade)

Student 5: For example, you just asked very good questions, 'What is a gene?' For example, I did not understand the definition of it exactly; maybe it is because I still do not understand the subject. 'What is a chromosome?', just as far as I know, [...] there is a line called chromosome big gene, I memorized that to learn the subject. I don't think the concepts were taught well, or they weren't received. In other words, I did not learn the concepts well, we need to start from scratch and learn, I think it is explained in a way as if we already know everything. Frankly, I haven't studied this subject very often. The concepts should have been taught first, 'what is a 
gene', 'what is a chromosome', then it had to be taught in-depth. (Male, age: $17 \mathrm{yr}$, 10th grade)

Student 3: There is confusion due to drawings and shapes. (Male, age: $16 \mathrm{yr}$, 9th grade)

Student 14: It may be because there are many foreign words. Some people have a different point of view, they don't like biology, but I think it's because there are a lot of foreign words and because it requires memorization [because]. And it's complicated, I mean, they are all so similar to each other. (Female, age: $18 \mathrm{yr}, 12 \mathrm{th}$ grade)

Interviewer: Are the words similar or their definitions?

Student 14: Words. For example, it is not the same as in Turkish, that is, when you add a letter, it is conjugated, but not in biology. When you add a letter, it can mean an entirely different thing. That's why. (Female, age: 18 yr, 12th grade)

Student 15: The reason they are confused with each other is because their meanings are similar. (Female, age: $16 \mathrm{yr}$, 9th grade)

As a result of the interviews conducted to obtain information about the students' misunderstandings about the basic concepts in genetics, it was concluded that a significant portion of the students has incorrect and inconsistent views about the basic concepts of genetics. It is seen that students have some knowledge about the phenomena, but they cannot form conceptual integrity with these phenomena.

\section{Conclusion and Discussion}

In this study, which aims to reveal the knowledge level of secondary education students about genetics and the source of this information, the data obtained from the interviews with the students were examined. As a general result, it has been found that students have inaccurate and inconsistent information about the basic concepts of genetics, have difficulties in establishing relationships between these concepts, and cannot fully understand and explain the processes underlying genetic events. These results are similar to the results of many studies in the literature (Bahar et al., 1999; Banet \& Ayuso, 2000; Dorji, Tshering, \& Dorji, 2017; Duncan \& Reiser, 2007; Finley et al., 1982; HaskelIttah, Duncan, Vazquez-Ben, \& Yarden, 2020; Stewart, 1982; Kindfield, 1991; Marbach-Ad \& Stavy, 2000; Rotbain et al., 2005; Tekkaya et al., 2001).

The findings obtained from the interviews revealed that some students confuse the concepts of gene, DNA, and chromosome with each other and therefore cannot explain the relationships between the concepts correctly. For example, it was found that some of the students think that DNA consists of chromosomes or that chromosomes are found in DNA. Similarly, Lewis et al. (2000c) found that the concepts of gene and 
chromosome are frequently used interchangeably. In another study, it is stated that students have a lot of confusion about the relationships between the concepts of gene, DNA and chromosomes (Wood-Robinson et al., 2000). Another issue that the students in the study were confused about is the location of the genes. Findings from interview questions towards the knowledge that genes that determine any trait are found in all cells showed that if students know the correct answer, then they also know the reason for the correct answer. However, when the wrong answers were examined, it was found that the rate of students who had the idea that genes are only found in the gametes was high. In another study with similar findings, Lewis et al. (2000c) concluded that a large number of students believe that only certain cells, especially those in the reproductive system, contain genetic information. In addition, the answers given to the related questions revealed that some students think that the gene that determines any trait is found only in the cell, tissue, or organ with that trait. These students believe that each cell contains only its own unique genes. In another study, it was found that most of the students believe that each cell type has different genes (Hackling and Treagust, 1984). Many students in this study stated that cells carry different genetic information according to their functions. Similarly, according to another research result, students think that cells contain only the genetic information they need to perform their functions (Lewis et al., 2000a). In addition, in the study, it was found that a very large portion of the students think that the sex chromosomes are only found in the gametes or reproductive organs. According to the results of other studies that have similar results with this finding, students think that only the gametes carry chromosomes and that these chromosomes are either X or Y (Lewis et al., 2000b; Chattopadhyay, 2005). It was observed that almost all of the students correctly answered the questions regarding the sex chromosomes, $\mathrm{X}$ and $\mathrm{Y}$ chromosomes, determining gender. However, it was found that the students did not have any other information about the functions of chromosomes, so when chromosomes were discussed, they only thought about sex chromosomes. Lewis and WoodRobinson (2000) in their research, in response to the question "Why are chromosomes important?" they mostly received the answer, "it determines the gender." In connection with this finding, it was understood that the students were not aware of the presence of both sex chromosomes and body chromosomes in all cells. It has been observed that students are very successful in solving genetic problems related to the number of chromosomes in situations that require mathematical operations. However, it has been found that they have difficulties in explaining how the number of chromosomes in cells is regulated. In addition, it was found that the students generally answered the questions about the characteristics of mitosis and meiosis correctly, but were unsuccessful in questions related to mitosis and meiosis.

These findings, which reveal the views of the students in the study about genetic concepts, show that the students have incorrect and missing information about the structure and location of these concepts and the relationships between the concepts. It has been observed that various factors have an effect on this result. One of these factors is the teaching of genetic concepts. Since the concepts are abstract and imaginary concepts, students have difficulty in understanding and they cannot achieve meaningful 
learning because they cannot establish a relationship between the concepts. It is seen that there is a need for more visual material in teaching genetic concepts and the concretization of abstract concepts. The results obtained from the interviews showed that as the grade level increases, the students use more and more diverse concepts related to genetics. However, it was also observed that the students had difficulty in providing indepth explanations. In addition, another result obtained from the interviews is that the students are not sure of the information they have. It is understood that this situation arises from the fact that students have incomplete and inconsistent information about basic concepts and subjects. This result shows that teaching basic concepts independently from each other makes it difficult for students to establish relationships between genetic events and concepts. At this point, it is considered important to emphasize the relationships between genetic concepts in teaching genetic events and processes. As a result, due to the lack of teaching about the abstract content of genetic concepts and the complex nature of genetic events, students have difficulty in establishing relationships between these concepts and cannot demonstrate an adequate understanding.

It has been found that another reason that students have difficulties in understanding genetic concepts is genetic terminology (Pearson \& Hughes, 1988a). Genetics has its own technical vocabulary. In parallel with new developments, new terms are added to the genetic terminology, which includes many synonymous concepts and words that are similar in spelling, or some terms are no longer used. For these reasons, genetic terms emerge as a factor that makes it difficult for students to understand genetics. In the interviews, most of the students stated that the genetic concepts are foreign to them. In addition, the facts that the words are similar to each other and the meanings of the expressions are similar cause the students to get confused. In another study on genetics, the same result was emphasized and it was stated that similar words cause confusion (Bahar et al., 1999). On the other hand, the wrong or careless use of genetic concepts in textbooks and by teachers causes students to not fully understand these concepts. Pearson and Hughes (1988b), in their study, reviewed various textbooks and identified misused genetic concepts. The researchers stated that this result caused both students and teachers to experience confusion about genetic concepts. The fact that genetics contains a large number of foreign and similar terms or they are incorrectly expressed causes students to confuse genetic concepts and not to understand them fully.

Another result that emerged during the interviews was that the students had some knowledge about genetic concepts but could not explain the reason for this knowledge. This result reveals that students partially know the facts, concepts, and events related to genetics, but they cannot understand the processes underlying genetic events. It has been understood that one of the important factors leading to this result is the university entrance exam. In our country, the university entrance exam consists of multiple-choice questions and the low number of biology questions within the scope of the exam affects students' study approaches and learning processes. In the distribution of questions by subject over the past three years, an average of 4 out of 160 questions was about cell divisions and genetics. Because this number is low and students find genetics topics difficult, some students ignore subjects related to genetics. Learning about 
genetics, which includes abstract concepts and complex relationships, requires more time and effort compared to other subjects. In this case, some students choose to learn genetics superficially and by rote memorization. In a study, it was stated that students tend to learn about genetics concepts separately, without establishing connections between them and structuring these concepts (Cavallo, 1996). However, learning genetic concepts by rote memorization results in students failing to use these concepts in different problem situations they encounter and also to explain the reasons for the knowledge they have.

The fact that some of the results obtained in the study are similar to the results of the relevant studies carried out many years ago (Banet \& Ayuso, 2000; Chattopadhyay, 2005; Lewis et al., 2000a; Lewis et al., 2000b; Lewis \& WoodRobinson, 2000; Marbach-Ad \& Stavy, 2000; Tekkaya et al., 2001) shows that the difficulties in the learning and teaching of genetic subjects and concepts continue to exist. At this point, it can be argued that an important contribution can be made by supporting teacher education in terms of current teaching approaches and the use of technological materials. In addition, updating the textbooks and source documents by enriching them with visual elements can be an effective solution. Considering that the invisible and inaccessible nature of genetic events is an obstacle to students' understanding, the need for a teaching environment supported by various animations and videos should be taken into account by teachers, education administrators, and curriculum developers. Since rote learning leads to unsuccessful results in understanding genetic concepts, it is also important for students to adopt a meaningful learning approach and to be guided in this direction.

\section{References}

Bahar, M., Johnstone, A.H., \& Hansell, M.H. (1999). Revisiting learning dificulties in biology. Journal of Biological Education, 33(2):84-89. DOI:

https://doi.org/10.1080/00219266.1999.9655 $\underline{648}$

Baker, W.P., \& Lawson, A.E. (2001). Complex instructional analogies and theoretical concept acquisition in college genetics. Science Education, 85:665-683. DOI: https://doi.org/10.1002/sce.1031

Banet, E., \& Ayuso, E. (2000). Teaching genetics at secondary school: A strategy for teach- ing about the location of inheritance information. Science Education, 84:313-351. DOI: https://doi.org/10.1002/(SICI)1098$237 \mathrm{X}(200005) 84: 3<313::$ AIDSCE2>3.0.CO;2-N

Boerwinkel, D.J., Yarden, A. \& Waarlo, A.J. (2017). Reaching a consensus on the definition of genetic literacy that is required from a twenty-first-century citizen. Science \& $E d$ ucation, 26:1087-1114. DOI: https://doi.org/10.1007/s11191-017-9934-y

Cavallo, A.M.L. (1996). Meaningful learning, reasoning ability, and students' understand- 
ing and problem solving of topics in genetics. Journal of Research in Science Teaching, 33(6):625-656. DOI:

https://doi.org/10.1002/(SICI)10982736(199608)33:6<625::AID-

TEA3>3.0.CO;2-Q

Chattopadhyay, A. (2005). Understanding of genetic information in higher secondary students in Northeast India and the implications for genetics education. Cell Biology Education, 4(1):97-104. DOI: https://doi.org/10.1187/cbe.04-06-0042

Cohen, L., Manion, L. \& Morrison, K. (2000) Research Methods in Education. 5th Edition, Routledge Falmer, London. DOI: http://dx.doi.org/10.4324/9780203224342

Dorji, K., Tshering, P., \& Dorji, U. (2017). Understanding of genetic entities: Exploration of Bhutanese students' conceptual status. Rabsel - the CERD Educational Journal, 18(2):11-25.

Duncan, R.G., \& Reiser, B.J. (2007). Reasoning across ontologically distinct levels: Students' understanding of molecular genetics. Journal of Research in Science Teaching, 44(7):938-959. DOI: https://doi.org/10.1002/tea.20186

Finley, F.N., Stewart, J., \& Yarroch, W.L. (1982). Teachers' perceptions of important and difficult science content. Science Education, 66(4):531-538. DOI: https://doi.org/10.1002/sce.3730660404

Gropengiesser, H. (2001). Didaktische Rekonstruktion des Sehens, Didaktisches Zentrum, Oldenburg, 240s.

Hackling, M.W., \& Treagust, D. (1984). Research data necessary for meaningful review of grade ten high school genetics curricula. Journal of Research in Science Teaching, 21(2):197-209. DOI:

https://doi.org/10.1002/tea.3660210210

Haskel-Ittah, M., Duncan, R.G., Vazquez-Ben, L., \& Yarden, A. (2020). Reasoning about genetic mechanisms: Affordances and constraints for learning. Journal of Research in Science Teaching, 57:342-367. DOI: https://doi.org/10.1002/tea.21595

Haskel-Ittah, M., Duncan, R.G., \& Yarden, A. (2020). Students' understanding of the dynamic nature of genetics: characterizing un- dergraduates' explanations for interaction between genetics and environment. $C B E$ Life Sciences Education, 19(3):1-13. DOI: https://doi.org/10.1187/cbe.19-11-0221

Hott, A.M., Huether, C.A., McInerney, J.D., Christianson, C., Fowler, D., Bender, H., Karp, R. (2002). Genetics content in introductory biology courses for non-science majors: Theory and practice. BioScience, 52(11):1024-1035. DOI: https://doi.org/10.1641/00063568(2002)052[1024:GCIIBC]2.0.CO;2

Johnson, S.K. \& Stewart, J. (2002). Revising and assessing explanatory models in high school genetics class: A comparison of unsuccessful and successful performance. Science Education, 86:463-480. DOI: https://doi.org/10.1002/sce.10015

Johnstone, A.H., \& Mahmoud N.A. (1980). Isolating topics of high perceived difficulty in school biology. Journal of Biological Education, 14(2):163-166. DOI: https://doi.org/10.1080/00219266.1980.1066 $\underline{8983}$

Kablan, H. (2004). An analysis of high school students learning difficulties in biology. Master Dissertation. Middle East Technical University, Ankara.

Kawasaki, H., Kawasaki, M., Iki, T., \& Matsuyama, R. (2021). Genetics education program to help public health nurses improve their knowledge and enhance communities' genetic literacy: A pilot study. BMC Nursing, 20(31). In press. DOI:

https://doi.org/10.1186/s12912-021-00549-8

Kılıç, D., \& Sağlam, N. (2014). Students' understanding of genetics concepts: the effect of reasoning ability and learning approaches. Journal of Biological Education, 48(2):6370, DOI: https://doi.org/10.1080/00219266.2013.8374 $\underline{02}$

Kılıç, D., \& Sağlam, N. (2009). Development of a two-tier diagnostic test to determine students' understanding of concepts in genetics. Eurasian Journal of Educational Research, 36:227-244.

Kindfield, A.C.H. (1991). Confusing chromosome number and structure: A common student error. Journal of Biological Education, 
25(3):193-200. DOI:

https://doi.org/10.1080/00219266.1991.9655 206

Knippels, M.P.J., Waarlo, A.J., \& Boersma, K.T. (2005), Design criteria for learning and teaching genetics. Journal of Biological Education, 39(3):108-112. DOI:

https://doi.org/10.1080/00219266.2005.9655 976

Lewis, J., Leach, J., \& Wood-Robinson, C. (2000a). What's in a cell? - Young people's understanding of the genetic relationship between cells, within an individual. Journal of Biological Education, 34(3):129-132. DOI: https://doi.org/10.1080/00219266.2000.9655 702

Lewis, J., Leach, J., \& Wood-Robinson, C. (2000b). Chromosomes: the missing link young people's understanding of mitosis, meiosis, and fertilisation. Journal of Biological Education, 34(4):189-199. DOI:

https://doi.org/10.1080/00219266.2000.9655 717

Lewis, J., Leach, J., \& Wood-Robinson, C. (2000c). All in the genes? - Young people's understanding of the nature of genes. Journal of Biological Education, 34(2):74-79.

DOI:

https://doi.org/10.1080/00219266.2000.9655 $\underline{689}$

Lewis, J., \& Wood-Robinson, C. (2000). Genes, chromosomes, cell division and inheritance do students see any relationship? International Journal of Science Education, 22(2):177-195. DOI:

https://doi.org/10.1080/095006900289949

Marbach-Ad, G. (2001). Attempting to break the code in student comprehension of genetic concepts. Journal of Biological Education, 35(4):183-189. DOI:

https://doi.org/10.1080/00219266.2001.9655 $\underline{775}$

Marbach-Ad, G., \& Stavy, R. (2000). Students' cellular and molecular explanations of genetic phenomena. Journal of Biological Education, 34(4):200-205. DOI: https://doi.org/10.1080/00219266.2000.9655 $\underline{718}$
Mayring, P. (2002). Einführung in die Qualitative Sozialforschung (5. Aufl.). Weinheim, Basel.

McLellan, E., MacQueen K.M., \& Neidig J.L. (2003). Beyond the qualitative interview: Data preparation and transcription. Field Methods, 15(1):63-84. DOI:

https://doi.org/10.1177/1525822X02239573

Okebukola, P.A. (1990). Attaining meaningful learning of concepts in genetics and ecology: An examination of the potency of the concept-mapping technique. Journal of Research in Science Teaching, 27(5):493-504. DOI:

https://doi.org/10.1002/tea.3660270508

Orcajo, T.I., \& Aznar, M.M. (2005). Solving problems in genetics II: Conceptual restructuring. International Journal of Science Education, 27(12):1495-1519. DOI:

https://doi.org/10.1080/09500690500186584

Pearson, J.T., \& Hughes, W.J. (1988a). Problems with the use of terminology in genetics education: 1 , a literature review and classification scheme. Journal of Biological Education, 22(3):178-182. DOI:

https://doi.org/10.1080/00219266.1988.9654 979

Pearson, J.T., \& Hughes, W.J. (1988b). Problems with the use of terminology in genetics education: 2 , some examples from published materials and suggestions for rectifying the problem. Journal of Biological Education, 22(4):267-274. DOI:

https://doi.org/10.1080/00219266.1988.9654 999

Rotbain, Y., Marbach-Ad, G., \& Stavy, R. (2005). Understanding molecular genetics through a drawing-based activity. Journal of Biological Education, 39(4):174-178. DOI: https://doi.org/10.1080/00219266.2005.9655 992

Stewart, J.H. (1982). Difficulties experienced by high school students when learning basic Mendelian genetics. The American Biology Teacher, 44(2):80-89. DOI: https://doi.org/10.2307/4447413

Stewart, J. \& Dale, M. (1989). High school students' understanding of chromosome/gene behavior during meiosis. Science Education, 
73(4):501-521. DOI:

https://doi.org/10.1002/sce.3730730410

Tekkaya, C., Özkan, Ö., Sungur, S., \&

Uzuntiryaki, E. (2001). Biology concepts

perceived as difficult by Turkish high school

students. Hacettepe University Journal of

Education, 21:145-150.

https://dergipark.org.tr/tr/pub/hunefd/issue/7 $817 / 102689$

Venville, G.J., \& Treagust, D.F. (1998). Exploring conceptual change in genetics using a multidimensional interpretive framework. Journal of Research in Science Teaching, 35(9):1031-1055. DOI:

https://doi.org/10.1002/(SICI)1098-

2736(199811)35:9<1031::AID-

TEA5>3.0.CO;2-E
Venville, G., Gribble, S.J., \& Donovan, J. (2005). An exploration of young children's understandings of genetics concepts from ontological and epistemological perspectives. Science Education, 89:614-633. DOI: https://doi.org/10.1002/sce.20061

Wandersee, J.H. (1985). Can the history of science help students educators anticipate students' misconceptions? Journal of Research in Science Teaching, 23(7):581-597. DOI: https://doi.org/10.1002/tea.3660230703

Wood-Robinson, C., Lewis, J., \& Leach, J. (2000). Young people's understanding of the nature of genetic information in the cells of an organism. Journal of Biological Education, 35(1):29-36. DOI: https://doi.org/10.1080/00219266.2000.9655 $\underline{732}$

Received: 24 September 2021

Revised: 12 October 2021

Accepted: 18 October 2021 